\title{
Forest management guidelines for forest-dwelling caribou in Québec
}

\author{
by Réhaume Courtois ${ }^{1,2,3}$, Jean-Pierre Ouellet ${ }^{2}$, Claude Dussault ${ }^{4}$ and André Gingras 5
}

The forest-dwelling ecotype of woodland caribou (Rangifer tarandus caribou) is vulnerable to predation, hunting, and disturbances due to anthropogenic activities. Its strategies of space and habitat use are oriented towards reducing the effects of these limiting factors. Caribou occupy large home ranges, undertake extensive movements, and avoid fragmented areas. They use various habitats, but especially mature and over-mature conifer stands with irregular structure, which are less suitable for other ungulates, wolves and black bears. In order to protect habitat for forest-dwelling caribou, we suggest an ecosystem approach based on the protection of large forested blocks, the concentration of forest harvesting in large management blocks, and the maintenance of habitat connectivity. This strategy focuses on short-term conservation of minimum caribou habitats in the protected blocks, a medium-term habitat recovery in the management blocks, the maintenance of forest activities, and facilitation of seasonal and dispersal movements. Within the management blocks, we recommend creation of an irregular forest structure similar to the pattern created by natural disturbances inherent to spruce-moss forests. These guidelines have been tested in Québec for the last few years and were well received by forest and wildlife agencies as well as the forest industry.

Key words: adaptive management, boreal forest, ecosystem management, forest-dwelling ecotype, forest management, spruce forest, woodland caribou

L'écotype forestier du caribou des bois (Rangifer tarandus caribou) est vulnérable à la prédation, à la chasse et aux dérangements anthropiques. Ses stratégies d'utilisation de l'espace et des habitats visent à réduire l'impact de ces facteurs. Il occupe de grands domaines vitaux, effectue de grands déplacements et évite les milieux fragmentés par la coupe et les perturbations naturelles. Il utilise différents habitats mais surtout les forêts résineuses matures et surannées de structure irrégulière moins propices aux autres cervidés et aux prédateurs. Pour aménager l'habitat du caribou forestier, nous recommandons une approche écosystémique basée sur la protection de grands massifs forestiers, la concentration des coupes forestières dans de grands blocs d'aménagement et le maintien de la connectivité des habitats. Cette stratégie permettra de conserver un habitat minimum à court terme, de reconstituer des habitats propices à moyen terme, de maintenir les activités forestières et de faciliter les mouvements saisonniers et la dispersion du caribou. À l'intérieur des blocs d'aménagement, nous proposons de s'inspirer du régime des perturbations naturelles ayant cours dans la pessière à mousses pour régénérer des forêts de structure irrégulière. Ces lignes directrices sont expérimentées au Québec depuis quelques années et elles furent bien reçues par les agences forestières et fauniques aussi bien que par l'industrie forestière.

Mots-clés : aménagement forestier, aménagement écosystémique, caribou des bois, écotype forestier, forêt boréale, gestion adaptative, pessière

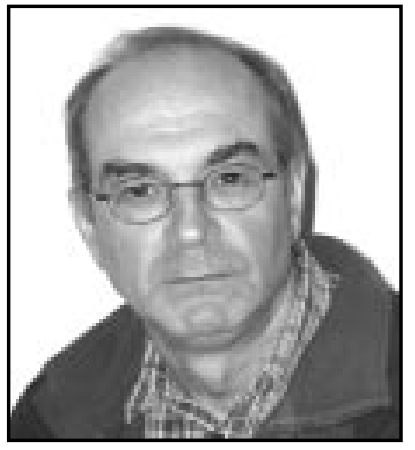

Réhaume Courtois

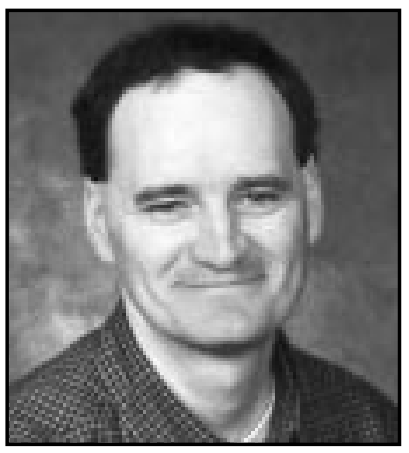

Jean-Pierre Ouellet

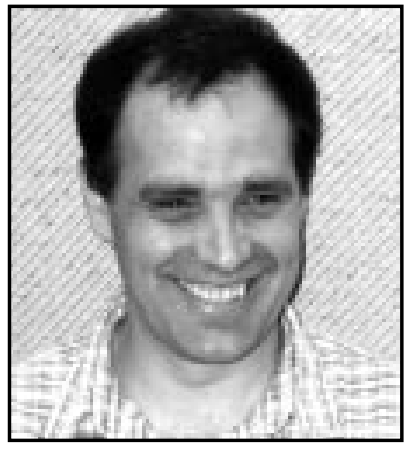

Claude Dussault

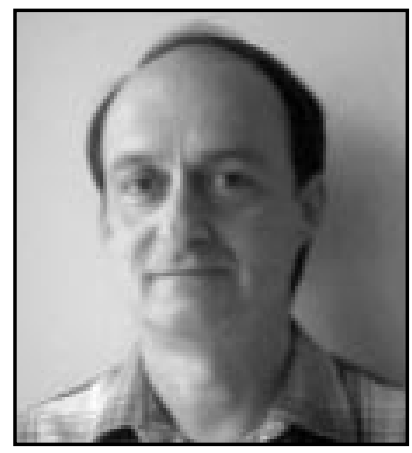

André Gingras

\footnotetext{
${ }^{1}$ Author to whom correspondence should be sent. Ministère des Ressources naturelles, de la Faune et des Parcs du Québec, Direction de la recherche sur la faune, 675, René-Lévesque, Est, 11 étage, boîte 92, Québec (Québec) G1R 5V7. E-mail: rehaume.courtois@ fapaq.gouv.qc.ca

${ }^{2}$ Université du Québec à Rimouski, Département de biologie et Centre d'études nordiques, 300, Allée des Ursulines, Rimouski (Québec) G5L 3A1.

${ }^{3}$ Université Laval, Département de foresterie et de géomatique, Cité Universitaire, Ste-Foy (Québec) G1K 7P4.

${ }^{4}$ Ministère des Ressources naturelles, de la Faune et des Parcs du Québec, Direction de l'aménagement de la faune, 3950 boul. Harvey, $4^{\mathrm{e}}$ étage Jonquière (Québec) G7X 8L6.

${ }^{5}$ Ministère des Ressources naturelles, de la Faune et des Parcs du Québec, Direction de l'aménagement de la faune, 818, boul. Laure Sept-Îles (Québec) G4R 1Y8.
} 


\section{Introduction}

Most woodland caribou (Rangifer tarandus caribou) populations of the forest-dwelling ecotype are declining in North America (Moisan 1956, Bergerud 1974, Mallory and Hillis 1998, Schaefer 2003). While excessive hunting and predation seem the proximate factor leading to caribou decline, it is likely that habitat modifications, especially forest cutting, are ultimately responsible (Seip 1991). Indeed, clearcutting drastically decreases the availability of suitable habitats, increases habitat fragmentation (Hanson et al. 1990, Caughley 1994), and accessibility, which facilitates hunting and predation (Cichowski 1996, Stuart-Smith et al. 1997, Rettie and Messier 1998). This situation lasts until natural processes reconstitute the original composition and structure of the forest. In some instances, conifer stands do not regenerate directly and are instead replaced by early successional species (Harvey and Bergeron 1989, Carleton and MacLellan 1994, Sirois 1997, Gagnon et al. 1998). Five to 15 years after cutting, these areas support abundant deciduous browse, providing prime habitat for moose (Alces alces) (Courtois et al. 1998). Higher moose densities then promote an increase in wolf (Canis lupus) abundance, which can exacerbate caribou predation (Seip 1992, AWCCSDC 1996). Caribou could eventually be extirpated if alternative prey thrive and sustain abundant wolf populations (Seip 1991). Early successional vegetation also favours increasing black bear (Ursus americanus) populations (Samson 2001), which may increase caribou calf and adult predation (Ballard 1994).

The protection of forest-dwelling caribou requires management measures directed to both habitat and population dynamics (Courtois 2003). In Québec, however, past management actions only dealt with caribou exploitation (Moisan 1956, Juniper 1979, COSEPAC 2000). Measures for habitat protection have remained diffident. Habitat protection regulations (L.R.Q., c. C-61.1) and forest harvesting guidelines (MRN 1996) acknowledge the importance of protecting calving, breeding, and wintering areas, but do not define these habitat features. Furthermore, protection is limited to groups of 50 or more caribou. These measures seemed satisfactory when they were enacted at the end of the 1980s because forest exploitation was less extensive and did not affect much caribou habitat at that time. However, major forest timber harvesting occurred in the province during the 1990s. Forest harvesting, mostly clearcuts, covered more than $70000 \mathrm{~km}^{2}$ during that decade, in addition to approximately $57000 \mathrm{~km}^{2}$ disturbed by fire, windfall, and insect outbreaks (MRN 2002). Due to a gradual northern expansion, the majority of forest harvesting now occurs in the core area of the forest-dwelling caribou range.

Considering the vulnerability of forest-dwelling caribou and the importance of the forest industry, it is crucial to develop management strategies that can ensure their coexistence. This is highly challenging since many past attempts have been unsuccessful (e.g., Cumming and Beange 1993, Hervieux et al. 1996), and because the actual forest industry guidelines (MRN 1996) mostly benefit moose and consequently wolves, to the detriment of caribou. In this context, we suggest guidelines promoting caribou conservation while minimizing the impact on allowable annual cuts. In this paper, we review the principal requirements of forest-dwelling caribou and propose a strategy adapted to this ecotype in Québec. These guidelines are based on an extensive literature review and on recent research studies (Courtois 2003).

\section{Principal Needs of Forest-Dwelling Caribou}

Habitat use by forest-dwelling caribou varies both regionally and seasonally, but mature coniferous forests, peatlands and open areas with terrestrial and arboreal lichens are the basic components (AWCCSD 1996, Stuart-Smith et al. 1997, Rettie and Messier 2000, Racey et al. 1999, Courtois 2003). In Québec, caribou are more common in areas subject to a very long forest fire cycle (200-500 years, Courtois et al. 2003b). They are highly vulnerable to predation, hunting and other anthropogenic disturbances (Bergerud 1974; Seip 1991, 1992; Dyer et al. 2001), and large areas of suitable habitat are required for caribou to persist in the presence of predators (Bergerud et al. 1984, Racey et al. 1999). Their space and habitat use strategies are adapted to reduce the impact of these limiting factors by using habitats less suitable for other cervids, wolves and black bears, by occupying large home ranges and undertaking extensive movements (AWCCSD 1997, Courtois et al. 2002). In central Québec, mature conifer stands with or without lichens, wetlands, and areas including large water bodies are preferred for home range establishment (Courtois 2003). During winter, lichen patches constitute predominant foraging sites for caribou (Racey et al. 1999, Johnson et al. 2001, Courtois 2003). During other seasons, caribou use habitats offering a compromise between foraging, predator avoidance, and mate association for breeding (Courtois 2003). Forest-dwelling caribou generally exhibit fidelity to sites used on a seasonal basis (Schaefer et al. 2000, Courtois 2003). Cuts in small blocks ( $<60$ ha; two- to three-pass system with sites logged once regeneration has reached 2-3 m) or with retention of small forest islands are not suitable for forest-dwelling caribou (Cumming and Beange 1993, Hervieux et al. 1996, Stuart-Smith et al.1997). These practices do not favour regeneration of the original composition of the forest, but instead promote regrowth of deciduous species, which contributes to increases in moose and wolves, hence to an increase in caribou predation (Bergerud 1974, Stuart-Smith et al. 1997 , Rettie and Messier 1998, Seip 1998, Courtois 2003).

\section{Forest Management for Forest-Dwelling Caribou}

Some forest-dwelling caribou populations live year-long in environments dominated by muskeg, fens and bogs. This is the case for populations in northern Alberta and Saskatchewan (Rettie et al. 1997, Stuart-Smith et al. 1997), and in certain areas of the Québec-Labrador peninsula (Brown et al. 1986, Paré 1987, Paré and Brassard 1994). In such environments, maintaining connectivity of marshland complexes is recommended, as well as a buffer zone around wetlands, and protection of wintering areas through restrictions on periods and intensity of logging activities (Stuart-Smith et al. 1997, Chamberland et al. 2000) (Table 1).

The majority of forest-dwelling caribou populations live all year in the boreal forest. These forest-dwelling caribou form groups during the fall and winter, generally in or nearby sites with suitable terrestrial lichen abundance (Johnson et al. 2001, Courtois 2003), and they disperse in the boreal forest during the spring and summer. Two management strategies have been proposed for forest-dwelling caribou in the boreal forest (Table 2). The first consists of identifying and protecting critical habitats, such as calving, breeding and wintering areas, then locating the main travel routes used between these habitats and maintaining large intact corridors around critical habitats and 
Table 1. Synthesis of forest management strategies proposed in the literature for the forest-dwelling caribou ecotype.

\begin{tabular}{|c|c|}
\hline Caribou living in major wetlands & Caribou living in forest environments \\
\hline $\begin{array}{l}\text { Characteristics } \\
\text { Association with large wetland environments } \\
\text { Use of forest islands present at low elevations } \\
\text { Grouping in winter } \\
\text { Dispersion in summer } \\
\text { Extensive movements } \\
\text { Fidelity to seasonal sites }\end{array}$ & $\begin{array}{l}\text { Characteristics } \\
\text { Association with spruce-moss forests } \\
\text { Preferences: } \\
\text { Dense mature conifer stands } \\
\text { Open conifer stands with lichens } \\
\text { Wetlands } \\
\text { Shores of large water bodies } \\
\text { Grouping in winter } \\
\text { Dispersion in summer } \\
\text { Extensive movements } \\
\text { Fidelity to seasonal sites } \\
\text { Vulnerability to hunting and predation } \\
\text { Foraging based on terrestrial lichens }\end{array}$ \\
\hline $\begin{array}{l}\text { Objectives } \\
\text { Protect conifer stands } \\
\text { Maintain terrestrial lichens } \\
\text { Maintain caribou movements }\end{array}$ & $\begin{array}{l}\text { Objectives } \\
\text { Protect critical habitats actually used by populations } \\
\text { Maintain terrestrial lichens } \\
\text { Promote caribou movements (predation, genetics) } \\
\text { Medium-term habitat recovery }\end{array}$ \\
\hline $\begin{array}{l}\text { Methods } \\
\text { Maintain connectivity of marshland complexes } \\
\text { Establish protection strips around wetlands } \\
\text { Protect wintering habitats }\end{array}$ & $\begin{array}{l}\text { Methods (see details in Table 2) } \\
\text { Two strategies are suggested: } \\
\text { Protection of critical habitats } \\
\text { Emulation of natural disturbances }\end{array}$ \\
\hline $\begin{array}{l}\text { Examples } \\
\text { Northern Alberta } \\
\text { Val-d'Or (Québec) } \\
\text { Québec Lower North Shore } \\
\text { Northern Québec }\end{array}$ & $\begin{array}{l}\text { Examples } \\
\text { Northern British Columbia } \\
\text { Ontario } \\
\text { Central Québec }\end{array}$ \\
\hline
\end{tabular}

travel routes (Cumming and Beange 1993, Cumming et al. 1996). This strategy is based on the premise that caribou show fidelity to critical habitats.

The second strategy, much more widely accepted, consists of emulating natural forest disturbance patterns (Racey et al. 1997, 1999; Simpson et al. 1997; Seip 1998; de Bellefeuille 2001). This strategy presupposes that forest-dwelling caribou are adapted to natural disturbances of the boreal forest (fires, insect outbreaks, windfalls) and will adapt to forest cutting practices that mimic them. Essentially, this approach involves silvicultural methods that emulate the structure, size, shape, and distribution of natural disturbances on a regional scale (Bergeron et al. 1999, 2002; de Bellefeuille 2001).

In order to emulate natural disturbances, one needs to know their inherent characteristics. First, forest fires, which are the most important disturbance agent of the boreal forest, can be characterized according to three axes of variability: cycle, extent, and severity (Gauthier et al. 2001, Bergeron et al. 2002). To generalize this principle to all disturbances, a fourth consideration, the origin (e.g., fires, insects and windfalls) must be added. In the boreal forest, these four variability axes create landscapes shaped primarily by large-scale fires, where large stands of mature and over-mature forest are fragmented by numerous small dispersed disturbances, and where large stands of young forest are interspersed with islands of old-growth stands unaffected by disturbances.

A three-stage process has been proposed to maintain the natural characteristics of forests and their biodiversity (Thompson and Welsh 1993, Hunter 1996, Potvin 1998, Bergeron et al. 1999). First, establishment of protected areas to maintain old-growth stands. Second, delineation of extensive forest management zones, where natural stand structures, age, composition, and spatial distribution would be maintained; this objective being reached by using silvicultural techniques that follow the pattern of the natural regime of perturbation and that consider socio-economic constraints (the ecosystem approach). Third, identification of zones of intensive management, where the goal would be to increase timber productivity to compensate for losses created by the establishment of protected areas.

The first stage of this strategy, i.e., preserving biodiversity at the provincial scale, will be accomplished through the network of protected areas currently under development in the province. Our guidelines address the second stage of the strategy in suggesting ways to manage habitat outside of the biodiversity network to ensure, simultaneously, the conservation of caribou and the forest industry in areas subject to timber harvesting. The third stage is still unaddressed.

\section{Strategy Proposed for Forest-Dwelling Caribou}

Within the range of forest-dwelling caribou in Québec, we recommend a management strategy that will protect portions of caribou seasonal habitats and will favour movement through habitat connectivity (Table 2). This approach would include the identification and temporary protection of large blocks of mature conifer stands linked by large tracts of forest. The protected blocks would be delimited in areas currently frequented by caribou. Outside these protected blocks, we propose concentrating logging activities in management blocks where regeneration of caribou habitat could be favoured. From this perspective, seven guidelines were formulated to provide direction in the development of forest management plans. 
Table 2. Two habitat management strategies suggested in the literature for forest-dwelling caribou in the boreal forest. The second strategy based on emulation of natural disturbances (ecosystem management) is suggested in this paper. This strategy takes into account regional peculiarities, specific characteristics of each population, regional forest management techniques and adaptive management.

Strategy based on protection of critical habitats
Assumptions
Caribou densities do not justify intense forest management
At the provincial scale
None
At the regional scale
None
At the management area scale
Identify areas used by caribou
Maintain a protection zone of $3 \mathrm{~km}$ around wintering areas

Strategy based on emulation of natural disturbances

Assumptions

The habitat is dynamic: wildfires, windfalls, insect outbreaks

Caribou are adapted to a regime of natural disturbances

Habitat is higher than actual caribou densities carrying capacity

At the provincial scale

Create protected areas to maintain biodiversity (parks, etc.)

Delimit a management zone for caribou (spruce-moss forest)

At the regional scale

Define conservation objectives (wildlife-forest)

Determine the nature, size, shape, and pattern of disturbances

Reproduce the pattern and structure created by natural fires

Identify areas used by caribou

Maintain a protection zone of $3 \mathrm{~km}$ around wintering areas
At the management area scale $\left(3000-7000 \mathrm{~km}^{2}\right)$

Identify critical areas

- Known wintering, calving and breeding areas (survey, telemetry)

- Potential sites (forest mapping, satellite images)

Delimit protected blocks $\left(100-250 \mathrm{~km}^{2}\right)$ and buffer zones

- Winter foraging (terrestrial lichens)

Calving (mature conifers, wetlands, water bodies)

Breeding (wetlands, conifers with lichens)

- Protection zone around known calving sites $(1000 \mathrm{~m})$

- Road network built outside the protected areas

Maintain habitat connectivity to favour caribou movements

- Movement corridors (2 km wide in young forests [> $3 \mathrm{~m}$ ] or $400 \mathrm{~m}$

wide in mature forests $[<80$ years])

- Locate corridors near residual habitats

- Avoid fragmentation (juxtaposition of small cuts)

Regenerate habitats for medium-term use

- Management blocks (concentrate logging areas)

- Maintain forest landscape composition

- Consider forest cycles (200-500 years)

- Consider maximum exploitation age

- Use diversified logging techniques

- Train machinery operators

Quantify habitats currently available

- Composition, structure, distribution

Avoid an increase in moose and wolf populations

- Promote conifer regeneration

- Joint management of caribou, moose, and wolves

- Predator control in threatened populations

At the site scale

Regenerate stand composition and structure

Promote conifer regeneration: avoid succession (deciduous stages)

Minimize access to protected blocks (temporary access)

Data source

Caribou surveys

Habitat surveys (forest maps, satellite images)

Monitoring (adaptive management)

${ }^{1} \mathrm{G} 1$ to $\mathrm{G} 7$ identify guidelines proposed in the text of this article.

\section{G1. Define the management area for forest-dwelling caribou}

In Québec, actual forest harvesting guidelines mainly focus on protecting streams, advanced regeneration, and soils (MRN 1996). Similarly, restrictions on size and distribution of cutovers in the forest landscape (mosaic cutting in blocks of 50-100 ha) promote the development of suitable habitat for moose and other edge species. Caribou are not well adapted to forest harvesting suitable for moose. The first step of forest management planning should consist of delimiting areas to be managed for caribou conservation, where management strategies that differ from those used for moose will be applied.

Data collected from various sources in Québec indicated that most caribou observations were made in spruce-moss forests (see Courtois et al. 2003b for a map). We propose to use the southern limit of this bioclimatic zone to define the forest-dwelling caribou management area. Current forest management regulations (MRN 1996) should be applied south of this zone, while the approach described hereafter should be applied in the forest-dwelling caribou range. Precise boundaries could be refined 
regionally to take into account administrative constraints and forest and wildlife peculiarities of each region.

\section{G2. Delimit protected blocks}

While highly variable, caribou annual home ranges typically cover 200-800 km² (Racey et al. 1999, Courtois et al. 2002), and a given population occupies between 10000 and 15000 $\mathrm{km}^{2}$ (Courtois et al. 2002), sometimes up to $40000 \mathrm{~km}^{2}$ (Brown et al. 1986). Gurd et al. (2001) suggested protection of $2700 \mathrm{~km}^{2}\left(2700-13296 \mathrm{~km}^{2}\right)$ areas to maintain the ecological integrity of the boreal forest and its wildlife. Protected blocks within the management area of forest-dwelling caribou are intended to conserve portions of caribou habitat, mainly wintering areas, to allow short- and medium-term ( $0-80$ years) maintenance of the species in an area, until logged areas again become suitable to fulfil caribou needs.

Because caribou have evolved in environments shaped by major forest fires, their movement strategies are dictated by predator avoidance and they usually search for mature forests (Bergerud et al. 1984, Courtois et al. 2002, Courtois 2003), protected blocks should cover large areas $\left(>100-250 \mathrm{~km}^{2}\right)$ and should include uneven-aged mature (80-140 years) and relatively mature (40-100 years; Racey et al. 1997) stands. The relatively large size of protected blocks is based on large home ranges and extensive movements of caribou, and is intended to minimize the risks of habitat loss due to forest fires, which will continue to rejuvenate large forested areas.

Caribou requirements change on a seasonal basis and caribou usually show fidelity to the sites they occupy (Schaefer et al. 2000, Courtois 2003). Protected blocks should therefore include a variety of habitat types. First, sites for winter foraging are needed. These are often unproductive sites (shallow soils, outcrops, eskers, sand dunes, wetlands; Racey et al. 1997, Stuart-Smith et al. 1997) with low tree density, generally not sought after by the forest industry (except for eskers and sand dunes, which are used to extract gravel for road construction). Protected blocks should also include potential sites for calving, which can vary regionally (large wetlands, large lakes with islands, chains of lakes bordered with mature conifers or wetlands), and should maintain buffer strips around known calving sites (e.g., managed area of $1000 \mathrm{~m}$; Racey et al. 1999).

Because it is unlikely that forest-dwelling caribou would easily adapt to harvesting of wintering areas, and because caribou are usually faithful to sites used on a seasonal basis (Schaefer et al. 2000, Courtois et al. 2002), protected blocks should be defined according to the wintering areas located during aerial surveys, which should be surrounded by a large buffer zone $(5-10 \mathrm{~km})$. Whenever possible, telemetry could be used to delimit the protected blocks (e.g., core areas with 50-60\% of pooled locations of 20-30 animals) and determine preferred habitats. The presence of terrestrial lichens (identified from satellite images; see Courtois 2003), large water bodies with islands and preferred habitats (established from telemetry in various studies) should be considered. Preferred habitats, not necessarily used by groups of caribou, should also be included in the protected blocks, in order to provide some alternative wintering areas (Racey et al. 1997). Eventually, caribou may use such sites if forest fires destroy their traditional sites. Abandonment of burned sites is a known adaptation of the species (Schaefer and Pruitt 1991).
Caribou are vulnerable to human disturbances and predation, and those living close to roads are most susceptible to predation (James and Stuart-Smith 2000). Road construction should be avoided in protected blocks to minimize habitat fragmentation and access by other ungulates, wolves, and humans. As much as possible, protected blocks should be located near forested lands with low potential for exploitation (no access, rough topography, wetlands, open stands and outcrops with or without lichens; Anonymous 2000b, de Bellefeuille 2001) or adjacent to large water bodies, especially if these contain islands (Anonymous 2001, de Bellefeuille 2001), because islands, particularly small ones, are not often used by predators (Bergerud 1985).

Protected blocks should be considered as sites designed for medium-term (60-100 years) caribou conservation. In order to maintain the allowable annual cut, protected blocks could be harvested once caribou have started using alternative habitats regenerated in unprotected areas. Where appropriate, the biodiversity network of protected areas and parks could serve as protected blocks for caribou, but obviously without consideration for forest harvesting.

\section{G3. Maintain habitat connectivity}

Protected blocks should be connected to maintain seasonal movements of caribou, reduce predation, and favour genetic exchange (Courtois et al. 2003a). Ideally, they should be linked by residual forests (open or young stands, inaccessible sites, wetlands, etc.). If that is not possible, corridors should be maintained ( $2 \mathrm{~km}$ wide in young forests [> $3 \mathrm{~m}$ ], Racey et al. 1997 or 400 $m$ wide in mature forests [ $<80$ years], Simpson et al. 1997) among the protected blocks. The 400-m-wide corridors should be restricted to $<500 \mathrm{~m}$ in length, within which forest harvesting should be banned. Partial cutting could be tested in the larger corridors. Corridors should be located near remnant forests. If possible, GPS telemetry could be used to identify movement routes or characteristics of sites frequented by caribou during seasonal movements. This would allow location of corridors in areas already used or with high potential. If detailed information is unavailable, Racey et al. (1999) suggested leaving mature or relatively mature forests along rough broken land features like rivers, chains of lakes, eskers, or mountain ridges. Sites located at altitudes $>400 \mathrm{~m}$ could be used during spring dispersion and calving as observed in central Québec (Courtois 2003).

One must caution that narrow or inadequately located corridors can be useless (Simberloff et al. 1992, Hannon and Schmiegelow 2002) if located in areas not used by caribou or if they do not provide required characteristics. Negative effects can eventually occur, for example, if corridors increase caribou concentration and consequently favour predation (Seip and Cichowski 1996). Despite these possible negative effects, at this stage it seems advisable to maintain corridors, but future research will be needed to determine their effectiveness.

\section{G4. Concentrate forest harvesting in management blocks}

Management blocks are aimed at maintaining timber harvest while focussing on the long-term (60-100 years) restoration of caribou habitat. In the short term, these management blocks could be used occasionally due to the development of herbaceous species or if terrestrial lichens were maintained, but forest harvesting techniques should be planned with the view to restore forest characteristics that prevailed before harvesting. 
The best way to do so would be to emulate the pattern created by natural disturbance processes. Management blocks could cover different surface areas, but generally they should be large (100-250 $\mathrm{km}^{2}$ ) and their size should be similar to the area normally burned by regional fires. Contrary to what is proposed in landscapes managed for moose (Samson et al. 2002), it would be advisable to concentrate cuts in management blocks to create large forested areas unsuitable for moose and wolves over the short term, while regenerating large caribou habitat tracts over the long term.

In the spruce-moss forest type, fire normally allows rapid establishment of black spruce regeneration without succession (Carleton and MacLellan 1994, Gagnon and Morin 2001). At maturity, these stands gradually open up following natural mortality, insect outbreaks, and windfalls (Gauthier et al. 2001). Forest management techniques should thus be chosen to favour reestablishment of the original stands (regeneration without succession) and to maintain stand composition and arrangement at the scale of the management block. Establishment of deciduous species in logged areas should be avoided to reduce chances for expansion by moose, wolves, and black bears. Expected long-term characteristics of the landscape (stand composition, size, distribution, etc.) must be determined according to the pre-cutting characteristics of the block.

Forestry practices should limit the impact on terrestrial lichens (e.g., winter cuts). Remnant forest stands, linked by corridors, and snags should be conserved within cutovers to favour caribou movements and colonization by arboreal lichens (Seip 1998). The forest structure created by fires could serve as a model to determine the proportion of forest to maintain in management blocks. For example, in western Québec, between 1 and $16 \%$ of the forest area affected by fires was preserved, and from 5 to $57 \%$ of the burned area maintained a predominantly green crown (Gauthier et al. 2001, Bergeron et al. 2002). These proportions are similar to those resulting from concentrated clearcuts in black spruce forests (Potvin et al. 2001).

In cut areas used by caribou, access to man should be limited by the use of winter forest harvesting and construction of temporary winter roads.

\section{G5. Maintain an irregular forest structure}

Forest-dwelling caribou are found in greater abundance in mature and post-mature forests (Racey et al. 1999), particularly in areas characterized by long fire cycles (Courtois et al. 2003b). A key feature of these stands is their uneven-aged structure (Gauthier et al. 2001) which should be maintained to mimic the evolution of natural disturbances. Lengthening the rotation period of forest harvesting is the primary way to maintain or promote the restoration of uneven-aged structure. To determine the optimal rotation period, the fire cycle needs to be determined on a regional basis and the optimal age for harvesting (when timber harvest volume starts declining) should also be considered. A rotation of 75 to 100 years seems too short, because it does not provide sufficient time for stands to develop an uneven-aged structure (Gauthier et al. 2001). It would also be advantageous to use partial cutting techniques (Bergeron et al. 1999, 2002) that could maintain the same proportion of uneven-aged stands that is actually found in a given management block; a higher proportion would require maintaining permanent roads and repeated harvesting (e.g., every 20 years) that would disturb caribou. Whenever possible, forest tracts should be maintained between unharvested stands within management blocks.
Diversification of forest management practices would allow maintenance of an uneven-aged distribution of stands within the landscape, similar to that produced by natural disturbances (Pothier 2001). For example, cuts with protection of regeneration and soils (CPRS), followed by scarification and planting, produces results similar to that of a fire in jack pine stands (Pothier 2001). The same technique used in a fir stand yields results similar to that of a severe insect outbreak (Pothier 2001). Precommercial and commercial thinning imitate light insect outbreaks by preserving some dominant and co-dominant trees (Pothier 2001). Fire control and planting in certain open spruce forests altered by natural or anthropogenic processes would contribute to maintaining black spruce dominance at the landscape level (Gagnon and Morin 2001). New types of partial cuts, such as cuts with protection of small merchantable trees (CPSMT) or cuts with protection of high regeneration and soils (CPHRS), could accelerate the reestablishment of spruce stands (Anonymous 2000a) and could imitate the structure and composition of old-growth forests. Moreover, these techniques could be used to limit the expansion of deciduous species.

These different types of cuts should be distributed at the landscape level to mimic the natural distribution of stand age classes in the landscape. To address this concern, Table 3 provides some examples of acceptable cuts in management blocks. For example, Bergeron et al. (1999) proposed the maintenance of three spruce age classes (cohorts) by using appropriate silvicultural techniques. Because jack pine and fir forests do not have the same optimal age of harvesting, the percentage represented by each of the three cohorts should vary with the species. The large-scale planting of spruce in open lichen woodlands, considered as non-productive sites by the logging industry, does not seem appropriate to maintenance of the original landscape composition because it would reduce the importance of potentially important foraging sources for caribou. For now, planting in lichen woodlands should be considered only in special cases and exclusively for experimental purposes.

\section{G6. Apply adaptive management}

Adaptive management assumes that scientific knowledge is provisory. It considers management to be an iterative process where decisions are guided by the results of former actions (Holling 1978, Grumbine 1994). We adhere to this philosophy. We believe that the strengths and weaknesses of our management guidelines will be revealed only during their application. Considering the diversity of caribou habitat (Cumming 1992), the importance of related issues and the complexity of processes involved, it is highly likely that our proposed strategy will need adjustments. Therefore, it will be important to monitor impacts on forests and wildlife, evaluate whether or not management objectives (i.e., maintain co-existence of caribou and forest harvesting, favour conifer regeneration, preserve lichens) are reached, and to implement retroactive mechanisms that could rectify management plans when necessary.

Monitoring of forest disturbance (cuts, natural regeneration, planting, and maintenance) would ensure that forest composition develops in the predicted fashion. For example, monitoring could verify whether or not forest management actions allow the reestablishment of desired forest characteristics (conifer regeneration, forest composition and structure, preservation of terrestrial and arboreal lichens, avoidance of deciduous species). As for wildlife monitoring, it is essential to 
Table 3. Example of proposed silvicultural practices in management blocks.

Logging aimed at simulating three

spruce cohorts at the landscape level ${ }^{2}$

\begin{tabular}{|c|c|c|c|c|}
\hline \multirow[b]{2}{*}{ Habitat type ${ }^{1}$} & \multirow[b]{2}{*}{$\begin{array}{l}\text { Secondary } \\
\text { characteristics }\end{array}$} & & & \\
\hline & & $\begin{array}{c}\text { Cohort } 1 \\
(31 \% \text { of the area })^{3} \\
\end{array}$ & $\begin{array}{c}\text { Cohort } 2 \\
(21 \% \text { of the area) } \\
\end{array}$ & $\begin{array}{c}\text { Cohort } 3 \\
(48 \% \text { of the area) } \\
\end{array}$ \\
\hline \multirow{3}{*}{$\begin{array}{l}\text { Closed spruce forests and } \\
\text { open spruce forests } \\
\text { without lichens }\end{array}$} & Black spruce regeneration & $\mathrm{CPRS}^{4}$ or CPSMT & PC, CPSMT, & Selective cutting \\
\hline & Uneven-aged & & CPHRS, CPRS & \\
\hline & $\begin{array}{l}\text { Balsam fir regeneration } \\
\text { Uneven-aged }\end{array}$ & $\begin{array}{l}\text { Precommercial thinning to } \\
\text { promote black spruce or } \mathrm{CC}, \\
\text { scarification, planting }\end{array}$ & $\begin{array}{l}\text { PC, CPSMT, } \\
\text { CPHRS, CPRS }\end{array}$ & Selective cutting \\
\hline \multirow{5}{*}{$\begin{array}{l}\text { Open spruce forests } \\
\text { with lichens }\end{array}$} & On moraine & $\mathrm{CC}$, scarification, planting to be & No intervention & No intervention \\
\hline & $\begin{array}{l}\text { Even-aged } \\
\text { Few layers }\end{array}$ & $\begin{array}{l}\text { considered on a small fraction } \\
\text { of this habitat type }\end{array}$ & & \\
\hline & On hard substrate & No intervention & No intervention & No intervention \\
\hline & Even-aged & & & \\
\hline & Few layers & & & \\
\hline \multirow{2}{*}{$\begin{array}{l}\text { Closed and open jack pine } \\
\text { forests without lichens }\end{array}$} & Even-aged & $\mathrm{CC}$, scarification, planting & No intervention & No intervention \\
\hline & No advanced regeneration & & & \\
\hline \multirow{2}{*}{$\begin{array}{l}\text { Open jack pine forests } \\
\text { with lichens }\end{array}$} & On moraine & $\mathrm{CC}$, scarification, planting & No intervention & No intervention \\
\hline & Even-aged & $\begin{array}{l}\text { to be considered on a small } \\
\text { fraction of this habitat type }\end{array}$ & & \\
\hline Fir forests & Uneven-aged & $\begin{array}{l}\text { CPRS or CC, scarification, } \\
\text { planting }\end{array}$ & $\begin{array}{l}\text { PC, CPSMT, } \\
\text { CPHRS, CPRS }\end{array}$ & Selective cutting \\
\hline In regeneration & - & $\begin{array}{l}\text { Maintenance to regenerate the } \\
\text { the stand of origin }\end{array}$ & $\begin{array}{l}\text { Maintenance to regenerate } \\
\text { the stand of origin }\end{array}$ & $\begin{array}{l}\text { Maintenance to regenerate } \\
\text { the stand of origin }\end{array}$ \\
\hline
\end{tabular}

Wetlands and others

No intervention; protection strips, corridors

Water bodies

Strips around lakes and streams

${ }^{1}$ Expected long-term percentage in the landscape must be determined from the pre-cutting situation.

${ }^{2}$ Connectivity between protected blocks will be needed at all times.

${ }^{3}$ Based on a 400-year forest cycle and a maximal harvesting age of 150 years (Bergeron et al. 1999).

${ }^{4} \mathrm{CC}=$ clearcut $\mathrm{PC}=$ partial cut; $\mathrm{CPRS}=$ cuts with protection of regeneration and soils; $\mathrm{CPSMT}=$ cuts with protection of small merchantable trees; CPHRS

$=$ cuts with protection of high regeneration and soils.

document how caribou react to managed areas. In particular, monitoring would help determine whether or not population density, recruitment and survival are maintained in management units, and if caribou use protected blocks, corridors and at least some parts of management blocks (i.e., partial cuts, CPRS with lichens, etc.). It is also important to determine whether or not caribou can survive in forest islands created by harvesting. Longterm studies comparing harvested and control areas should be undertaken at least in some areas because the negative effects of forest harvesting could take decades to become apparent.

Management and monitoring plans should be designed by multi-party and multidisciplinary regional teams, to ensure that management plans simultaneously respect the needs of caribou, industry, wildlife and other forest users, while stimulating the regional economy.

The application of adaptive management has been attempted in some instances. For example, the guidelines presented in this paper have been used to conclude a three-party (wildlifeforest-industry) administrative agreement in part of management unit 093-20, on the North Shore of the St. Lawrence River (Anonymous 2000b), and a wildlife-forest monitoring program has been implemented (Anonymous 2000c). Data collected in that program will contribute to assessment of the management plan's benefits and to correct its weaknesses. Similar projects involving two or more management units are about to be implemented (Anonymous 2001, Lafleur et al. 2002).

\section{G7. Experimental ecosystem management}

Forest management planning should adhere to a global philosophy promoting sustainable use of forest resources. Ecosystem management seems the best approach to reach this goal. This natural resource management philosophy proposes that sustainable development is achieved if the integrity and functions of an ecosystem are preserved, and if humans are considered as one component of the ecosystem (Gerlach and Bengston 1994). Ecosystem management aims to promote long-term protection of natural ecosystem integrity by incorporating scientific knowledge about ecological interactions and value judgments in a socio-political context (Grumbine 1994). It is a holistic approach oriented towards fulfilment of ecological, social and economical needs, ultimately aimed at finding solutions that are ecologically sustainable, economically viable, and socially acceptable, through a perpetual cycle of planning, implementation, monitoring, and adjustments involving citizens, government, and industry (Gilmore 1997). This paradigm states that there is not a single exclusive good deci- 
sion, but rather an array of decisions that seem to better fulfil the actual and future needs of society, as revealed during the decision-making process (Lackey 1998).

Guidelines have been formulated to clarify the abstract concept of ecosystem management (Burton et al. 2003). For species of interior forests (e.g., caribou), Irland (1994) suggests options to maintain the primitive characteristics of the forest, for example by focusing on spatial and temporal objectives in the proportion, distribution and structure of old-growth forests, by limiting access to the territory, and by preserving large blocks of mature forests. Landscape characteristics such as connectivity, critical habitat components, and fragmentation should also be considered through rigorous planning and coordination (for wildlife and forests), spatial data acquisition, and sophisticated forest management recommendations. For the boreal forest in eastern Canada, Kneeshaw et al. (2000) suggested standards based on biodiversity, forest productivity, soil conservation, and protection of aquatic fauna. Bergeron et al. (2002) proposed strategic planning and the application of silvicultural techniques to maintain variability in forest composition and structure at different landscape levels. Our guidelines are another way to implement ecosystem management in areas used by forest-dwelling caribou.

\section{Conclusion}

The suggested approach seems an acceptable short-term (five years) solution for forest and wildlife managers, as well as for the forest industry. In Québec, a five-year plan for aerial surveys has already been implemented to identify sites to be protected in areas subject to forest harvesting. Monitoring programs will contribute to the evaluation of the effectiveness of the current guidelines. In 10 to 30 years, partial cutting might be considered within protected blocks to maintain annual allowable cut. In such a case, it would be appropriate to concentrate harvesting in a way that maintains the largest possible undisturbed areas. For example, partial cutting of a third of the protected blocks every 30 years might be appropriate. A research project has been planned to test this approach.

Caribou declines have been attributed to hunting and predation, exacerbated by habitat modification (Seip 1991, AWCCSDC 1996, Cichowski 1996, Stuart-Smith et al. 1997, Rettie and Messier 1998). Caribou conservation consequently necessitates direct and concomitant approaches to both forest and wildlife management. Adequate habitat management measures will favour a long-term equilibrium among caribou, moose, wolves and black bear populations. Over the short term, the prohibition of forest-dwelling caribou hunting will minimize direct human impact on populations (Courtois 2003). Adequate management of moose hunting could help to avoid increases in abundance of wolves. Wolf and black bear target densities, and allowable annual harvest of each, should be established with a view toward caribou conservation. Finally, direct predator control could be considered for very vulnerable or recovering populations (Seip 1998) to ensure short-term survival of caribou, while the causes of decline are identified and permanent solutions implemented. However, predator control should not be considered as a "half-way technology" (Frazer 1992) justifying inaction against anthropogenic landscape alterations or excessive hunting.

\section{Acknowledgements}

The authors are indebted to Sonia de Bellefeuille, Pierre Drapeau, James Schaefer, François Potvin, Arthur Rodgers and one anonymous referee who commented on an earlier version of this paper. The project was financed by the Ministère des Ressources naturelles, de la Faune et des Parcs du Québec, the Association des manufacturiers de bois de sciage du Québec, the Fondation de la faune du Québec, Abitibi-Consolidated Inc. and Kruger (Scierie Manic).

\section{References}

Anonymous. 2000a. Vif intérêt pour l'aménagement s'inspirant de la nature. Info-Forêts, juin 2000: 11-14.

Anonymous. 2000b. Plan d'aménagement de l'habitat du caribou de l'aire commune 093-20. Scierie Manic Inc. (Kruger), Société de la faune et des parcs du Québec. Ministère des Ressources naturelles, Sept-Îles. 10 p. + cartes.

Anonymous. 2000c. Plan d'aménagement de l'habitat du caribou de l'aire commune 093-20. Programme de suivi 2000-2005. Société de la faune et des parcs du Québec, Direction de l'aménagement de la faune de la Côte-Nord, Sept-Îles. 6 p.

Anonymous. 2001. Plan d'aménagement du caribou forestier, Saguenay-Lac-Saint-Jean. Société de la faune et des parcs du Québec, Jonquière. Unpaged.

AWCCSDC. 1996. Alberta's woodland conservation strategy. Draft \# 100. Alberta Woodland Caribou Conservation Strategy Development Committee. 55 p.

Ballard, W.B. 1994. Effects of black bear predation on caribou - A review. Alces 30: 25-35.

Bergeron, Y., B. Harvey, A. Leduc and S. Gauthier. 1999. Stratégies d'aménagement forestier qui s'inspirent de la dynamique des perturbations naturelles : considérations à l'échelle du peuplement et de la forêt. For. Chron. 75: 55-61.

Bergeron, Y., A. Leduc, B. Harvey and S. Gauthier. 2002. Natural fire regime: a guide for sustainable management of the Canadian boreal forest. Silva Fennica 36: 81-95.

Bergerud, A.T. 1974. Decline of caribou in North America following settlement. J. Wildl. Manage. 38: 757-770.

Bergerud, A.T. 1985. Antipredator strategies of caribou: dispersion along shorelines. Can. J. Zool. 63: 1324-1329.

Bergerud, A.T., R.D. Jakimchuk and D.R. Carruthers. 1984. The buffalo of the North: caribou (Rangifer tarandus) and human development. Arctic 37: 7-22.

Brown, W., J. Huot, P. Lamothe, M. Paré, G. St-Martin and J.B. Theberge. 1986. The distribution and movement patterns of four woodland caribou herds in Québec and Labrador. Rangifer, Spec. Issue 1: 43-49.

Burton, P.J., C. Messier, D.W. Smith and W.L. Adamowicz (ed.). 2003. Towards sustainable management of the boreal forest. National Research Council Research Press, Ottawa, ON. 1039 p.

Carleton, T.J. and P. MacLellan. 1994. Woody vegetation responses to fire versus clear-cutting logging: a comparative survey in the central Canadian boreal forest. Écoscience 1: 141-152.

Caughley, G. 1994. Directions in conservation biology. J. Anim. Ecol. 63: 215-244.

Chamberland, C., M. Paré and J. Thiboutot. 2000. Plan d'aménagement du site faunique du caribou au sud de Val-d'Or, 1999-2004. Ministère des Ressources naturelles, Société de la faune et des parcs du Québec, Rouyn-Noranda. 40 p.

Cichowski, D.B. 1996. Managing woodland caribou in west-central British Columbia. Rangifer, Spec. Issue 9: 119-126.

COSEPAC. 2000. Espèces canadiennes en péril, novembre 2000. Comité sur la situation des espèces en péril au Canada, Ottawa. 26 p.

Courtois, R. 2003. La conservation du caribou forestier dans un contexte de perte d'habitat et de fragmentation du milieu. $\mathrm{PhD}$ Thesis, Université du Québec à Rimouski, Rimouski. 350 p. 
Courtois, R., L. Bernatchez, J.-P. Ouellet and L. Breton. 2003a. Significance of caribou ecotypes from a genetic viewpoint. Conserv. Genetics 4: 393-404.

Courtois, R., J.-P. Ouellet, L. Breton, A. Gingras and C. Dussault. 2002. Effet de la fragmentation du milieu sur l'utilisation de l'espace et la dynamique de population chez le caribou forestier. Société de la faune et des parcs du Québec, Québec. 44 p.

Courtois, R., J.-P. Ouellet and B. Gagné. 1998. Characteristics of cutovers used by moose (Alces alces) in early winter. Alces 34: 201-211.

Courtois, R., J.-P. Ouellet, A. Gingras, C. Dussault, L. Breton and J. Maltais. 2003b. Historical changes and current distribution of caribou, Rangifer tarandus, in Québec. Can. Field-Nat. 117: 399-414. Cumming, H.G. 1992. Woodland caribou: facts for forest managers. For. Chron. 68: 481-491.

Cumming H.G. and D.B. Beange. 1993. Survival of woodland caribou in commercial forests of northern Ontario. For. Chron. 69: 579-588.

Cumming, H.G., D.B. Beange and G. Lavoie. 1996. Habitat partitioning between woodland caribou and moose in Ontario: the potential role of shared predation risk. Rangifer, Spec. Issue 9: 81-94.

de Bellefeuille, S. 2001. Le caribou forestier et la sylviculture. Revue de littérature et synthèse de la recherche et de l'aménagement en cours au Québec. Ministère des Ressources naturelles, Québec. 91 p. Dyer, S.J., J.P. O'Neill, S.M. Wasel and S. Boutin. 2001. Avoidance of industrial development by woodland caribou. J. Wildl. Manage. 65: 531-542.

Frazer, N.B. 1992. Sea turtle conservation and halfway technology. Conserv. Biol. 6: 179-184.

Gagnon, R. and H. Morin. 2001. Les forêts d'épinette noire du Québec: dynamique, perturbations et biodiversité. Nat. Can. 125: 26-35.

Gagnon, R., J. Potvin and É. Gagné. 1998. Les bases écologiques du fonctionnement des forêts commerciales d'épinette noire du Saguenay-Lac-Saint-Jean - Chibougamau-Chapais (Québec): vers un aménagement forestier durable. Université du Québec à Chicoutimi, Chicoutimi. 27 p.

Gauthier, S., A. Leduc, B. Harvey, Y. Bergeron and P. Drapeau. 2001. Les perturbations naturelles et la diversité écosystémique. Nat. Can. 125: 10-17.

Gerlach, L.P. and D.N. Bengston. 1994. If ecosystem management is the solution, what's the problem? J. For. 92 (8): 18-21.

Gilmore, D.W. 1997. Ecosystem management - A needs driven, resourceuse philosophy. For. Chron. 73: 560-563.

Grumbine, R.E. 1994. What is ecosystem management? Conserv. Biol. 8: 27-38

Gurd, D.B., D.N. Thomas and D.H. Rivard. 2001. Conservation of mammals in eastern north American wildlife reserves: how small is too small? Conserv. Biol. 15: 1355-1363.

Hannon, S.J. and F.K.A. Schmiegelow. 2002. Corridors may not improve the conservation value of small reserves for most boreal birds. Ecol. Appl. 12: 1457-1468.

Hanson, J.S., G.P. Malanson, and M.P. Armstrong. 1990. Landscape fragmentation and dispersal in a model of riparian forest dynamics. Ecol. Model. 49: 277-296.

Harvey, B.D. and Y. Bergeron. 1989. Site patterns of natural regeneration following clear-cutting in northwestern Québec. Can. J. For. Res. 19: 1458-1469.

Hervieux, D., J. Edmonds, R. Bonar and J. McCammon. 1996. Successful and unsuccessful attempts to resolve caribou management and timber harvesting issues in west central Alberta. Rangifer, Spec. Issue 9: 185-190.

Holling, C.S (ed.). 1978. Adaptive environmental assessment and management. John Willey and Sons, New York.

Hunter, M. 1996. Benchmarks for managing ecosystems: are human activities natural? Conserv. Biol. 695-697.

Irland, L.C. 1994. Getting from here to there - implementing ecosystem management on the ground. J. For. 92 (8): 12-17.
James, A.C., A.K. Stuart-Smith. 2000. Distribution of caribou and wolves in relation to linear corridors. J. Wildl. Manage. 64: 154-159. Johnson, C. J., K. L. Parker, and D. C. Heard. 2001. Foraging across a variable landscape: behavioral decisions made by woodland caribou at multiple spatial scales. Oecologia 127: 590-602.

Juniper, I. 1979. Le niveau des prises actuel du caribou au QuébecLabrador. Rech. Amérindiennes Québec (1-2): 159-164.

Kneeshaw, D.D., A. Leduc, P. Drapeau, S. Gauthier, D. Paré, R. Carignan, R. Doucet, L. Bouthilier and C. Messier. 2000. Development of integrated ecological standards of sustainable forest management at an operational scale. For. Chron. 76: 481-493.

Lackey, R.T. 1998. Seven pillars of ecosystem management. Landscape Urban Plann. 40: 21-30.

Lafleur, P.-E., R. Courtois, D. Banville and A. Sebbane. 2002. Proposition d'un plan d'aménagement forestier pour le territoire fréquenté par le caribou de Charlevoix. Société de la faune et des parcs du Québec, Charlesbourg. $16 \mathrm{p}$.

Mallory, F.F. and T.L. Hillis. 1998. Demographic characteristics of circumpolar caribou populations: ecotypes, ecological constraints/releases, and population dynamics. Rangifer, Spec. Issue 10: 49-60.

Moisan, G. 1956. Le caribou de Gaspé I. Histoire et distribution. Nat. Can. 83: 225-234.

MRN. 1996. Règlement sur les normes d'intervention dans les forêts du domaine public. Ministère des Ressources naturelles du Québec, Québec. F-4.1, r.1001.1.

MRN. 2002. Rapport sur l'état des forêts québécoise, 1995-1999. Ministère des Ressources naturelles du Québec, Charlesbourg. 272 p.

Paré, M. 1987. Effets du remplissage d'un réservoir hydroélectrique sur la population de caribous de Caniapiscau. MSc Thesis, Université Laval, Ste-Foy. 141 p.

Paré, M. and C. Brassard. 1994. Écologie et plan de protection de la population de caribous de Val-d'Or. Ministère de l'Environnement et de la Faune du Québec, Rouyn-Noranda. 56 p.

Pothier, D. 2001. Portrait de la forêt boréale québécoise. Nat. Can. 125: 5-9.

Potvin, F. 1998. La martre d'Amérique (Martes americana) et la coupe à blanc en forêt boréale : une approche télémétrique et géomatique. PhD Thesis, Université Laval. 245 p.

Potvin, F., R. Courtois and C. Dussault. 2001. Fréquentation hivernale de grandes aires de coupe récentes par l'orignal en forêt boréale. Société de la faune et des parcs du Québec, Québec. 35 p. Racey, G., A. Harris, T. Amstrong, L. Gerrish, R. Schott, R. McNicol and R. Gollat. 1997. Landscape planning for the conservation of forest-dwelling woodland caribou, northwestern Ontario. Ontario Ministry of Natural Resources, Thunder Bay. 53 p.

Racey, G., A Harris, L. Gerrish, T. Armstrong, J. McNicol and J. Baker. 1999. Forest management guidelines for the conservation of woodland caribou: a landscape approach. Ontario Ministry of Natural Resources, Thunder Bay. 69 p.

Rettie, W.J. and F. Messier. 1998. Dynamics of woodland caribou populations at the southern limit of their range in Saskatchewan. Can. J. Zool. 76: 251-259.

Rettie, W.J. and F. Messier. 2000. Hierarchical habitat selection by woodland caribou: its relationship to limiting factors. Ecography 23: 466-478.

Rettie, W.J., J.W. Sheard and F. Messier. 1997. Identification and description of forested vegetation communities available to woodland caribou: relating wildlife habitat to forest cover data. For. Ecol. Manage. 93: 245-260.

Samson, C. 2001. Que savons-nous de l'ours noir dans la forêt boréale? Nat. can. 125 (3): 74-80.

Samson, C., C. Dussault, R. Courtois and J.-P. Ouellet. 2002. Guide d'aménagement de l'habitat de l'orignal. Société de la faune et des parcs du Québec, Fondation de la faune du Québec et ministère des Ressources naturelles, Ste-Foy. 48 p.

Schaefer, J.A. 2003. Long-term range recession and the persistence of caribou in the taiga. Conserv. Biol. 17: 1435-1439. 
Schaefer, J., C.M. Bergman and S.N. Luttich. 2000. Site fidelity of female caribou at multiple spatial scales. Landscape Ecology 15: 731-739.

Schaefer, J.A. and W.O. Pruitt. 1991. Fire and woodland caribou in southeastern Manitoba. Wildl. Monogr. 116: 1-39.

Seip, D.R. 1991. Predation and caribou populations. Rangifer, Spec. Issue 7: 46-52.

Seip, D.R. 1992. Factors limiting woodland caribou populations and their interrelationships with wolves and moose in southeastern British Columbia. Can. J. Zool. 70: 1494-1503.

Seip, D.R. 1998. Ecosystem management and the conservation of caribou habitat in British Columbia. Rangifer, Spec. Issue 10: 203-211. Seip, D.R. and D.B. Cichowski. 1996. Population ecology of caribou in British Columbia. Rangifer, Spec. Issue 9: 73-80.

Simberloff, D., J.A. Farr, J. Cox and D.W. Mehlman. 1992. Movement corridors: conservation bargains or poor investments? Conserv. Biol. 6: 493-504.
Simpson, K., E.T. Terry and D. Hamilton. 1997. Toward a mountain caribou management strategy for British Columbia - habitat requirements and sub-population status. British Columbia Ministry of Environment, Victoria. 29 p.

Sirois, L. 1997. Distribution and dynamics of balsam fir (Abies balsamea [L.] Mill.) at its northern limit in the James Bay area. Écoscience 4: 340-352.

Stuart-Smith, A.K., J.A. Corey, S. Boutin, D.H. Hebert and A.B. Rippin. 1997. Woodland caribou relative to landscape patterns in northeastern Alberta. J. Wildl. Manage. 61: 622-633.

Thompson, I.D. and D.A. Welsh. 1993. Integrated resource management in boreal forest ecosystems - Impediments and solutions. For. Chron. 69: 32-39. 